\title{
A COMPREHENSIVE OVER 100 YEARS HISTORY OF MOUFLON (OVIS MUSIMON) IN POLAND: FROM THE PROMISING BEGINNING IN 1902 TO QUESTIONABLE FUTURE IN 2014 - A CASE STUDY OF WILDLIFE MANAGEMENT HISTORY
}

\author{
NASIADKA, P. $.^{*}-$ WAJDZIK, M. ${ }^{2}-$ SKUBIS, J. ${ }^{3}$ \\ ${ }^{I}$ Department of Forest Zoology and Wildlife Management, Institute of Forest Sciences, Warsaw \\ University of Life Sciences, ul. Nowoursynowska 159, 02-776 Warsaw, Poland \\ ${ }^{2}$ Department of Forest Biodiversity, Faculty of Forestry, University of Agriculture in Cracow, \\ Al. 29-Listopada 46, 31-425 Kraków, Poland \\ (e-mail: rlwajdzi@cyf-kr.edu.pl; phone: +48-60-477-5704) \\ ${ }^{3}$ Department of Wildlife Management and Forest Protection, Faculty of Forestry, Poznań \\ University of Life Sciences, ul. Wojska Polskiego 71 D, 60-625 Poznań, Poland \\ (e-mail: skubis@up.poznan.pl; phone: +48-50-719-2365) \\ *Corresponding author \\ e-mail:nasiadek@wl.sggw.pl; phone: +48-60-834-2007 \\ (Received $15^{\text {th }}$ Apr 2020; accepted $27^{\text {th }}$ Jan 2021)
}

\begin{abstract}
Mouflon (Ovis musimon) is an alien species in Poland, and a good example of how former customs in hunting become a problematic situation in modern wildlife management. The objective of the study was to document the history of the mouflon, its introductions and the reason for their failures, as well as the changes in population numbers between 1902 and 2014. The history of mouflons was tracked in three periods: 1902-1945, 1946-1981, and 1982-2014. The earliest introductions took place in the Sudeten mountains in 1902. About 50\% of next introductions were unsuccessful because of severe winters, lack of supplemental feeding, poaching, and predation by stray dogs, as well as the consequences of inbreeding. Currently less than 3.000 mouflons inhabit the Sudeten mountains in south and the lowlands in western Poland. They occur in 23 local populations. In all locations, mouflon inhabit big forests which represent typical stands composition and potential understory sites. In mountains there are Picea abies stands on Dentario Enneaphyllidis-Fagetum sites, and in lowlands - Pinus sylvestris stands on Galio SilvaticiCarpinetum sites respectively. Unfortunately, existing populations need constant protection by hunters that cause legitimate questions about the sense of further breeding of this species for the purpose of hunting.
\end{abstract}

Keywords: alien species, introductions, hunting, history of wildlife management, Poland

\section{Introduction}

At least two features of the mouflon (Ovis musimon, synonymously known as $O$. ammon, $O$. gmelini, $O$. aries) turn it into an exceptional ungulate species occurring in Poland. Firstly, unlike the red deer (Cervus elaphus L.), roe deer (Capreolus capreolus L.) or wild boar (Sus scrofa L.) the mouflon, is a typical forest wild ungulate and all existing populations or introductions undertaken in the past took place in large and dense forest complexes. Forests were to be the area where mouflons should enrich the hunted fauna and, actually, mouflons presently inhabit them causing much less damage to farm crops, so typically ascribed to the deer family (Tomiczek and Türcke, 2003; Cerkal and Muska, 2010).

The second feature (expressed even in its Latin names) is that although the mouflon is inseparably linked to the history of humans in Europe, very little is known about the 
origin and ecology of this large herbivorous species introduced outside the area of its natural habitat (Geist, 1991; Nasiadka et al., 2015).

Discussions used to arise already at the level of origin, and taxonomic classification of the species, which in the last 100 years or so has been thoroughly modified (Chessa et al., 2009). Basically, they concerned the number of wild sheep species and mouflon's ranking among them. At the beginning of the $20^{\text {th }}$ century the mouflon was regarded as one of four or even nine species of wild sheep (Lydekker, 1913; Nasonov, 1923; Heindleder et al., 2002). Later, in the 1950s, Tsalkin (1951) narrowed the number of species to one $-O$. ammon or two - O. ammon and O. nivicola/canadensis. In the 1970s, when the species began to be distinguished on the basis of the number of chromosomes, Nadler and et al. (1973) suggested the division of wild sheep into four groups with the mouflon $(O$. musimon) being classified into one group with the urial $(O$. vignei) and the argali $(O$. ammon). Unfortunately, both Nadler and et al. (1973), and Valdez and et al. (1978) pointed out to the fact that different species of wild sheep in the areas of their joint occurrence (e.g. northern Iran) can interbreed with each other and produce fertile offspring. This only further complicates the systematics of the species concerned (Nadler et al., 1971).

If the IUCN definitions are to be respected, at present, mouflons should be regarded as one of three wild Eurasian sheep, along with the argali and urial.

Yet another issue which has not been conclusively solved pertains not only to the origin of the species itself but of the mouflons occurring in Europe contemporarily. The question is whether they are indeed the primordial forms of wild sheep which migrated to Europe from Central Asia, or if they are a feral form of sheep previously domesticated, a hybrid between domesticated sheep and mouflons or perhaps yet another combination of domesticated sheep and their wild counterparts (Heindleder et al., 2002).

Domesticated primitive sheep, which arrived in Europe 10 to 4 thousand years B.C. during the so-called Neolithic Revolution, could have been the ancestors of mouflons (Wilson and Reeder, 2005). At that time, the development of agriculture as well as the domestication of animals took place in the region of the Fertile Crescent (areas along the Tigris, Euphrates and Nile rivers). These processes were followed by the increase in human populations and migrations of people (Barker, 2006; Simmon, 2007). It was very likely that during the a.m. agricultural revolution one or several species of the CentralAsian wild sheep were domesticated (O. orientalis, O. musimon?). They are thought to have settled, first, in the Mediterranean basin together with migrating people. Then, either with advancing civilization or as animals escaping from farms, they colonized areas further north. However, these populations no longer exist. The mouflon, thus, disappeared completely from the continent of Europe about three thousand years B.C., whereas the animals remaining from Neolithic introductions on Sardinia and Corsica gave rise to the next stage of the European history of this species (Payne, 1968).

The undisputable fact is that all mouflon populations now living in the wild in Europe originated, more often than not, from intentional introductions. At present, the European range of distribution of the mouflon covers 21 countries, although the population numbers in these countries differ considerably. The most numerous populations which consist of more than $50 \%$ of the total number of European mouflons live in three countries: the Czech Republic (ca. 20\%), Germany (ca. 19\%), and Hungary (ca. 13\% of the European population). Some 30\% of mouflons inhabit three more countries: Austria, continental France, and Slovakia. The remaining group of 15 countries is inhabited by local populations numbering no more than 1-2 thousand individuals in separate, isolated groups (Tomiczek and Türcke, 2003). 
The introductions of mouflons, both those in the early 20th century and those carried out after the Second World War, were aimed, principally, at the introduction of an additional hunted species or - in sporadic cases - of animals for breeding purposes. At that time, the validity of introducing an alien species for hunting purposes was not questioned. The mouflon was a little-known species, had a different appearance than native species and had an interesting trophy (i.e. horns). This was enough for the species to spread all over continental Europe. Now, the mouflon is a game species in 20 European countries. Hunting the species is most popular in Slovakia, the Czech Republic and Hungary, where the horns are highly valued as trophies among hunters. In the remaining European countries, mouflons are hunted in order to control their local population numbers, but also for their horns and, not less importantly, for their meat (Tomiczek and Türcke, 2003).

Poland is a country where the mouflon definitely represents a niche species, numbering approximately 3000 individuals, and their clustered distribution is linked to introduction programmes. Compared with its populations in the neighbouring countries of the Czech Republic or Slovakia, in Poland the mouflon is not regarded as an attractive trophy animal (Wajdzik et al., 2014). Moreover, not being a native species among the native fauna, it sometimes raises discussions on its future fate and triggers critical voices on the justification for maintaining local populations (Szczęśniak, 2011; Dębiec, 2014). On the other hand, however, the mouflon is a hunted species in Poland, consequently the hunters are legally obliged by law - The Act on Hunting, to protect this species and to care for its preservation (Brachmański, 2011).

Unfortunately, the current state of knowledge about the Polish mouflon is so poor that, practically, crucial decisions cannot be taken and the dilemma remains unsolved (Nasiadka et al., 2015). Evident proof of this may be the fact that so far the only bibliography devoted to mouflons, and their history on Polish territory, dates from the early 1950s (Szczepkowki in 1951). Publications from later years have a very diverse form (from press reports to the results of a few studies) and are scattered in many sources. What is more, these materials were mostly published in Polish and are practically unavailable to scientists dealing with wild ungulates and their history in Europe.

This paper was aimed at gathering and summing up as many details as possible on the history over 100-year-long presence of the mouflon in Poland, its introductions, changes in population numbers, and reasons for failures, as of 1902, i.e. from the first introduction of this species to the areas that are presently on Polish territory.

One of the objectives of this paper was also to discuss the further fates of either introduced or spontaneously emerging populations of this species outside its natural range of distribution. The history of the mouflon in Poland can be a very good example of a fragment of the history of European wildlife management (dead end?), when during over 100 years the focus has been shifted from hunting - breeding and shooting for the trophy (for the quantity and quality of as many species as possible) to the sustainable management of native species populations to preserve them and protect their habitats (Riley et al., 2002).

\section{Methods}

Research studies on the history of introductions and on current distribution and size of the populations of mouflons in Poland were performed for three time periods: 19021945, 1946-1981, and 1982-2014 using two types of sources. The very periods of time 
were primarily dictated by the different quality and availability of source data that varied depending on the specific period to which they pertained.

No statistical data (from foresters or hunters) was available for the years 1902-1945, thus the history of mouflons in that period was reconstructed, primarily, on the basis of the data contained in publications by authors of the time. When describing the first occurrences of mouflons in the present territory of Poland, these authors often provided data on the numbers of released mouflons, their origin, as well as on either the development or the reasons for the failure of breeding efforts. This data is the sole and extremely valuable source of information about mouflons. Furthermore, the specificity of years 1902-1945 consisted in a stormy history resulting, among others, in the changes of borders within Europe, due to which Poland reappeared on the map of the continent in 1918. This period was characterized by high geopolitical dynamics. Over short periods, depending on the specific state an area belonged to, the systems of management, data collection and its archivisation in the same area could change significantly. The same changes regarded game animals and hunting. A short period of stabilisation between 1918 and 1939 was followed by a further extensive 'reshuffling' of states, their borders, and political systems, similar to what had occurred two decades earlier.

After 1945, the territory of Poland shifted west by several hundred kilometers, onto lands previously belonging to Germany. This had a significant effect on the presence of mouflons among hunted animal species in Poland. Scarce and inadequate hunting statistics was one of the consequences of the difficult post-war era, and these no longer exist. In the 1950s the principal source of information about mouflons were, as in earlier years, a few press releases, and the first Polish monograph of the mouflon written by Szczepkowski (1951). This data has often been the only preserved evidence of the introductions of mouflons (i.e. the origins of local populations) and their fortunes in subsequent years. In the same period, methods of inventories of game animals as well as hunting data bases were developed and standardized. It finally led to a unified system for monitoring populations of hunted animals which consisted in calculating the estimated number of hunted animals at the end of "game management year", i.e. on 31 March. The responsibility for running these inventories falls on some 2,500 hunting clubs which lease about 4,700 hunting grounds, as well as on 430 forest districts, and, to a lesser extent, on 23 national parks.

Since 1982, data coming from hunting clubs, i.e. from the highest number of wildlife habitats, is transferred to a databank at the Research Station of the Polish Hunting Association in Czempiń near Poznań city. Since then, a standardised system has been in operation not only for data collection on game animals, but also for keeping the data and processing it (e.g. for the purposes of national statistics by the Central Statistical Office of Poland). Therefore, the 1982 to 2014 (to time of changes in rules of data preparing by hunting clubs in 2014) period was treated in our study as the third substantially cohesive period of mouflons inhabiting Poland. Information about this period comes from hunting statistics and from statistics of the State Forests National Forest Holding.

The term "successful introduction" in these studies means that a local mouflon population exists from the time of the first introduction to the present day. The fact whether there were additional re-introductions in the meantime or not, or whether there were periods when mouflons did not occur in a given area (practically there were no such situations), does not affect the meaning of the definition: successful introduction. 
The mouflons were after the first introduction, the mouflons are now, it means that the introduction was successful.

The paper uses official and commonly available geographical names of mountain ranges in which there are or there were mouflons in Poland.

The names of the forest districts and their locations are taken from the official State Forest National Forest Holding catalog: https://www.bdl.lasy.gov.pl/portal/en

\section{Results}

\section{The beginning. Years 1902-1945}

Although the mouflon appeared on the present-day territory of Poland in 1902, its earlier history and arrival on the European continent is worth mentioning. There is no doubt that the contemporary European mouflon populations came from Sardinia and/or Corsica, and that they were first introduced to the Vienna area in 1730 (Tomiczek and Türcke, 2003). According to mentioned authors, the other milestones important to the development of mouflon population in Europe, include: 1858 - their introduction to the area of Hluboka (presently the Czech Republic); 1868 - introductions to the Jelenec area (Slovakia); 1870 - introduction to the Casentino area (central Italy); 1902 introductions in the Sudeten mountains (Poland); 1903 - Gohrde region (northern Germany), and in 1906 - in the Harz mountains (Germany) (Tomiczek and Türcke, 2003). Another date that deserves particular attention is 1899 as it marks the beginning of mouflon breeding in Hungary near Betler. The breeding there began with 47 animals brought in from Linz in Austria (Jezierski, 1955).

As mentioned earlier, the first mouflons were brought to lands in present-day Poland in 1902. According to Łabęcki (2008), it was Count von Seidlitz-Sandreczki - one of many representatives of German-Czech-Polish families of the Sudeten region, who came out with the idea of the introduction (Labęcki, 2008). He brought five mouflons from the hunting ground of Nagyappone in Slovakia, and introduced them to the Sowie mountains, near Bielawa village. The breeding progressed well, and in 1929 this mouflon herd amounted to about twenty individuals. Next came successful introductions to the Karkonosze mountains - in the period 1912-1913, in the Central Sudeten mountains near Wałbrzych in 1913 and 1921, and in the Śnieżnik massif - in 1928-1929 (Piegert and Uloth, 2000). At that time, the German introductions were very successful. Up to the outbreak of the Second World War, this region was inhabited by approximately 200-300 mouflons and their number, despite huntings, continued growing.

In 1934, mouflons were released in another region of Poland, namely in the Carpathians. Four ewes and two rams were brought there from Hamburg and, after a year spent in a pen, they were let loose together with their lambs. This location also proved correct. The originators of the project decided to select a mountainous area in the Starzawa Forest District (henceforth abbreviated as F.D.) - presently the Ukraine, which was free of such large predators as wolf, lynx and brown bear, actually not an easy task in the Western Carpathians at the time (Szczepkowski, 1951). Until 1939, this region was inhabited by ca. 20 individuals. They survived the war there, and traces of their presence can be found in the first Russian post-war publications about fauna of Ukraine (Szczepkowski, 1951 after Bobrinskij et al., 1944). At the beginning of the 1960s this population ceased to exist. 
The lowland forests of Spała in Central Poland, was the next mouflon introduction site in Poland. Mouflons were brought to the Spalskie Forests in 1937. These were two rams and four ewes which gave birth to lambs the following year. Unfortunately, any further breeding efforts were thwarted by war, and the fate of the animals kept in the several-hectare large enclosure remains unknown (Szczepkowski, 1951; Jezierski, 1955).

Very little is known about the introduction of mouflons during the II WWR. However, at least three attempts are known to have been undertaken by Germans. The first was performed in 1939 in the forested hills of the Gdańsk Pomeranian region near Kartuzy (now the Kartuzy F.D.). Nine animals were released there and they survived until 1946 (Szol and Olej, 1946; Nowak, 1968).

The remaining two introduction attempts took place in 1941 and 1942, in the lowland forests of western Poland, in the Notecka Primeval Forest. At first, they consisted in enclosure-based breeding of mouflons which were subsequently released into the wild. In what is now the Wronki F.D., breeding started with four rams and ten ewes and they were at first kept in an enclosure. These mouflons were released in 1942. One year later, another breeding attempt began in the Sieraków F.D., and - in the same year - after a short quarantine period, the mouflons (their initial number remains unknown) formed a wild population there (Nowak, 1968). From post-war publications it is known that the breeding in those locations had been initially successful. Up to the end of war, 30 and 35 mouflons survived in Sieraków and Wronki, respectively (Nowak, 1968). Their numbers later declined. In 1948, 23 mouflons were still alive in Sieraków, whereas only 9 individuals remained in Wronki (Ostrowski, 1949). According to Nowak (1968), the year 1950 should be regarded as the end date of these populations (Nowak, 1968).

The above-mentioned releases were not the only ones that were attempted during the Second World War. Some others, whose history cannot be reconstructed today, include the presence of about ten mouflons in the period 1947-1949 near the city of Bytom in southern Poland (Ostrowski, 1949). This group, observed over three years and considered large for mouflons, must have arrived in the area still before 1945. A similar situation occurred in the area near Torun, where mouflons were observed shortly after the war. In 1949, two individuals of unknown origin were spotted there (Nowak, 1968). The close distance to the pre-war border with Germany and the large forested lands in this area also allow the presumption that a breeding site of mouflons had existed in this part of the country before the end of WWII. The 1902-1945 locations of successful introductions and releases of mouflons, as well as the sites where the animals have failed to survive in the area of contemporary Poland are presented in Figure 1.

\section{Years 1946-1981. Better documentations, worse statistics}

The papers and simple statistics published in these years showed that, basically, in the post-war period the presence of mouflons in Poland was documented, and the widespread failure of introductions and the declines in numbers of local populations were widely discussed (Nasiadka et al., 2015).

In addition to the already existing populations, two attempts to introduce mouflons to lowland forests were undertaken between 1946 and 1981. The first was carried out in the north of the Mazovia region and ended in failure. In 1950, two rams and four ewes purchased in the former Czechoslovakia were placed in a quarantine enclosure in the Ciechanów F.D. According to Nowak (1968), one released pair did not survive (poaching, predation by stray dogs) and because of that the remaining four animals were 
transferred to another location, which remains unknown. The second introduction was carried out more than two decades later in the Pomeranian forests of Sławno F.D. In 1973, three rams and two ewes were released there, and one year later, five more ewes were added. All these animals started a local population which still exist today (Solarz, 2011).

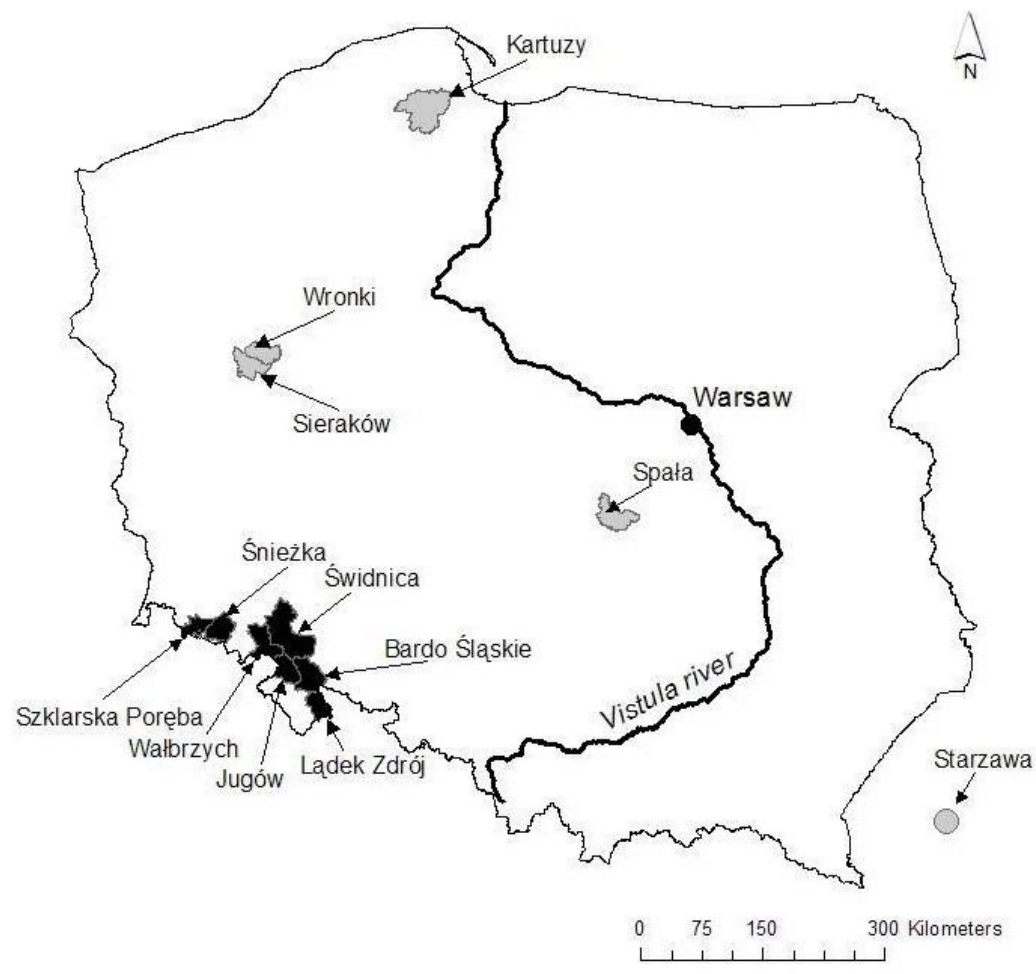

Figure 1. Introductions of mouflons in Poland during years 1902-1945 (black coloursuccessful, gray-failed introductions)

Another attempt to introduce mouflons to the Świętokrzyskie mountains (the Lagów F.D.) - the only mountain range in Poland that is not connected to the country's mountainous region in the south - ended in a rather dramatic fashion. In 1952, two rams, one ewe, and two lambs brought from the Sudeten mountains were placed in a quarantine enclosure. In the same year, at the beginning of winter, the mouflons were released and thus a wild population was formed. Four years later, in 1956, as many as seven mouflons were recorded there (Nowak, 1968), and after two more years, in 1958, this population was reinforced by four more rams and five ewes from Czechoslovakia (Krysztofik, 1962). The same author reported on the successful development of the population in the Świętokrzyskie mountains which in 1962 amounted to as many as 2530 animals inhabiting both managed forests and the National Park. This situation did not last long, however, because it was already in 1965 when the population ceased to grow, whereas in subsequent years it collapsed completely. Nowak (1968) reported that at the beginning of 1968, there were a mere three mouflons living in the Świętokrzyskie mountains, while the last confirmed sighting was made in 1973 (Nowak, 1968; Solarz, 2011). This year can be deemed to mark the end of the history of mouflons in the area. 
The years between 1946 and 1980 witnessed dynamic changes also at the sites of the first introductions at the beginning of the 20th, namely in the Sudeten mountains. These mountains consist of a number of smaller ranges where introductions took place at various times with strongly variegated sizes of local mouflon populations. Labęcki (2008) also reported on an interesting natural introduction (migrations) of mouflons. In line with his report, as of 1948 there were sightings of mouflons in the Stołowe mountains, that were not introduced either before or after the war. Taking into consideration the fact that they were large-sized herds numbering: 54 individuals in 1948, 151 in 1949, and as many as 195 in 1950, it is justified to assume that these mouflons originated in the Czech population. In 1957, the last records were made of 22 mouflons in the Stołowe mountains, and thereafter the population vanished until 1989 (Łabęcki, 2008).

Similar events occurred in the Kamienne and Wałbrzyskie mountains. Prior to 1945, in these locations there had been no introductions. However, in the 1948-1958 there were records of several to even several dozen mouflons (Szczepkowski, 1951; Łabęcki, 2008). In subsequent years, the presence of the species was noted sporadically up until 1987. Since that date, the present-day population has inhabited that area.

The introduction of mouflons in the Kaczawskie mountains (the Jawor F.D.), i.e. outside the Sudeten mountains, has been successful. The first group of animals: five rams and ten ewes, were brought there in 1969 from Germany, from the Uhlenstein F.D. in the Harz mountains. The animals were released from pen in 1970. Since that year there has been a free-roaming herd of mouflons, which was "beefed up" by more animals in the following years: by four rams and five ewes in 1971, and by three rams and eight ewes in 1976 (Labęcki, 2008) (Fig. 2).

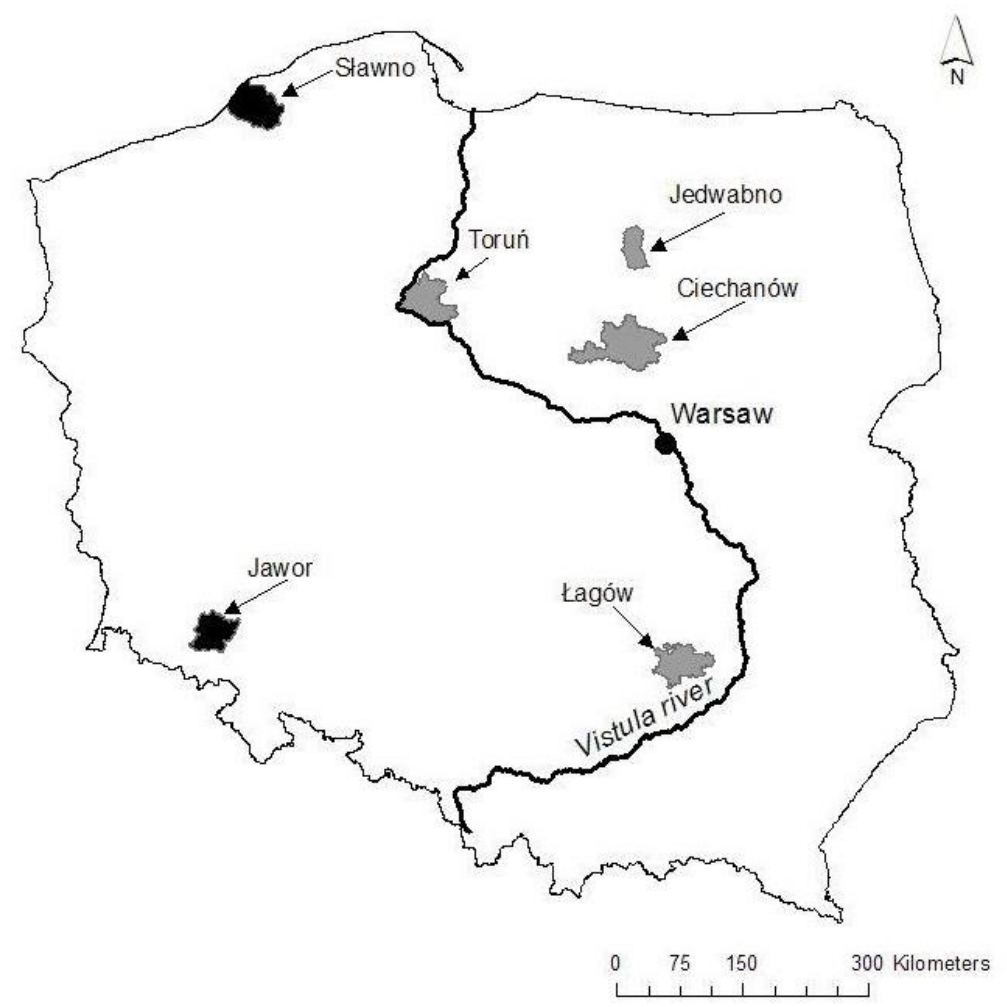

Figure 2. Introductions of mouflons in Poland during years 1946-1981 (black coloursuccessful, gray-failed introductions) 


\section{2-2014. Better statistics, worse information}

This period has two distinctive features in Poland. The first is the increased interest in mouflons, their purchases and introductions among hunting clubs, as well as the emergence of the issue of the adverse effect of mouflons on the environment (Jakubowski and Zalewski, 2000; Bobek et al., 2014). Compared with earlier decades, this period is referred to as a "renaissance" of scientific interest in mouflons in Poland (Nasiadka et al., 2015).

The second feature, unfortunately of an adverse nature when seen from the viewpoint of the consequences of introduction of alien species, involves the increased number of uncontrolled introductions and almost no information about the reasons for failures in this period.

In the aforementioned last three decades, mouflons were reported in a total of more than 50 locations in the lowland part of Poland, and continuously monitored in the Sudeten mountains (Fig. 3).

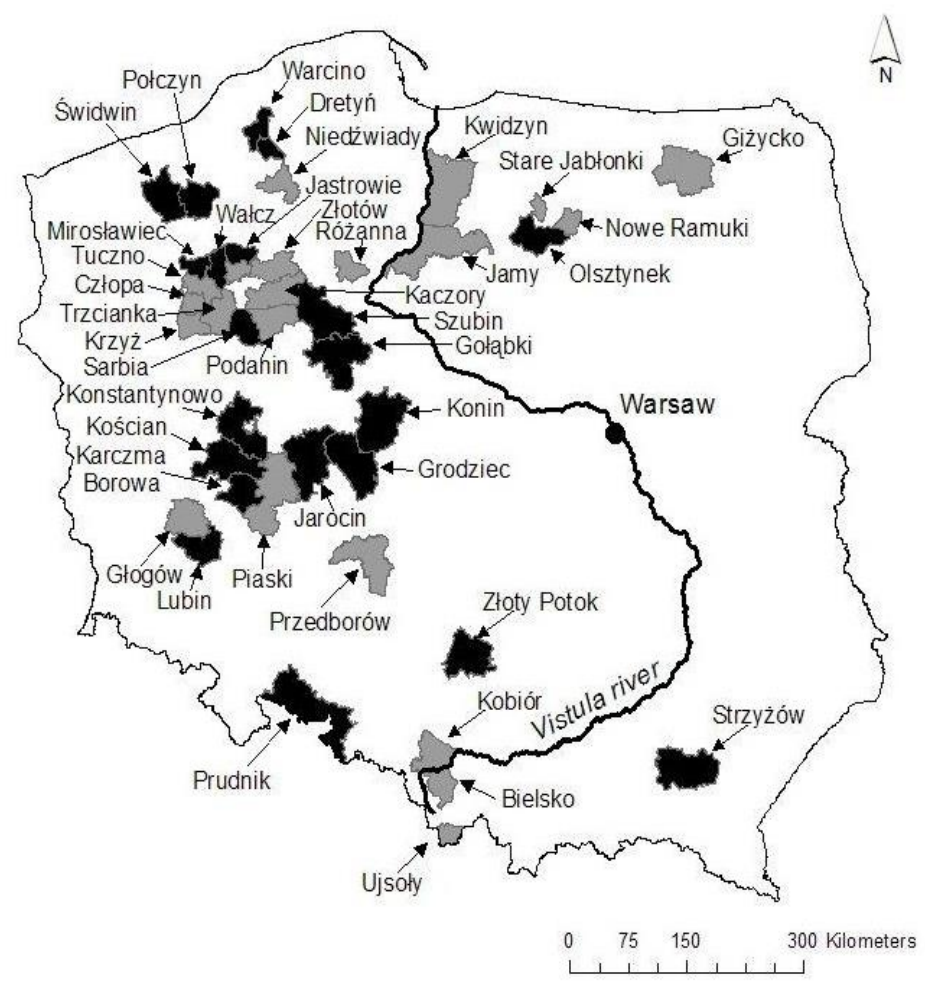

Figure 3. Introductions of mouflons in Poland during years 1982-2014 (black coloursuccessful, gray - failed introductions)

The intensity of introductions has been uneven. Initially, in 1982-1991 mouflons were brought to six F.D., including three forested areas in the northeastern part of the country: Olsztynek, Stare Jabłonki, and Nowe Ramuki; single site in the lower Vistula river basin - Jamy F.D.; Wałcz F.D. in the Pomerania in northern Poland; and Bielsko F.D. in Upper Silesia.

In the following ten years (1992-2001), the number of introductions rose to nine. However, the highest number of introductions and observations of "fugitives" (usually single animals) was noted in the next period, i.e. the years 2002-2011. Hunters released 
and observed groups of 1-20 mouflons - a total of 191 individuals - in 27 places distributed throughout the whole of Poland.

In the above-referred period, the introductions of mouflons did not take place only in central and eastern Poland, i.e. the least forested areas and with severe climate.

In recent years (2012-2014), the intensity of releases has also been quite high. Just in the last three years, hunters have confirmed the presence of 39 mouflons in four new locations: in Jarocin, Świdwin, Krzyż and Połczyn F.D. (Fig. 4a).
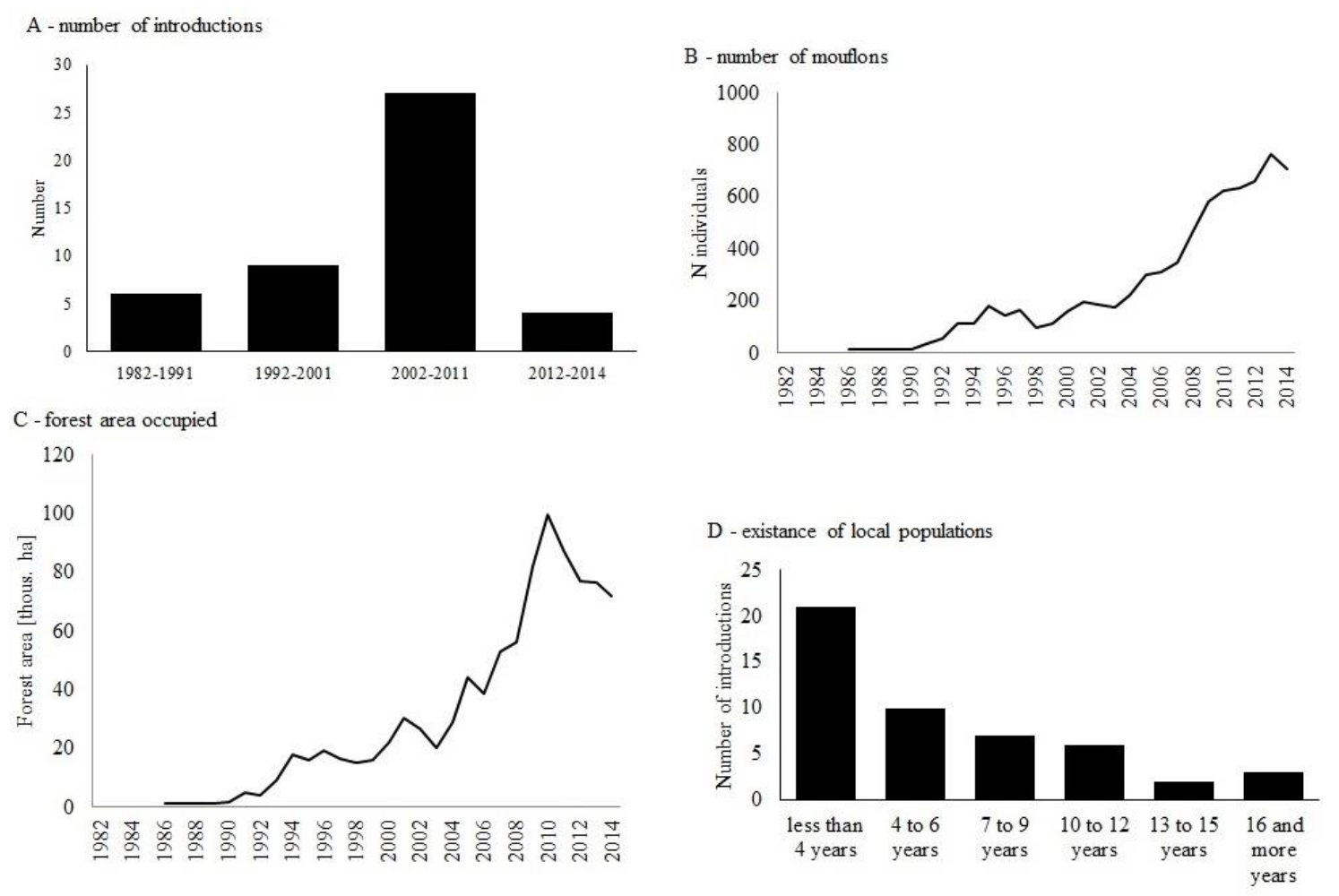

Figure 4. Characteristics of introductions and history of local populations of mouflons in lowland Poland during the period of 1982-2014

Despite earlier attempts, lowland mouflon population arose only at the end of the period 1982-2014. At the beginning of this period, only a few to a dozen mouflons lived at large. Over time, there has been an increase in the number of introductions and mouflon population increased to about 700 individuals in 2014. It is worth mentioning that the first successful release of mouflons in that period, carried out in a typical lowland landscape, took place as late as in 1986 in the region of Masuria, in the Olsztynek F.D. The increase in numbers in that period shows two phases. In the first phase (1982-2001) it was slow and strongly correlated with the intensity of releases which was then minor. In subsequent years, beginning in 2002, the mouflon population grew systematically, slowly at the beginning, and rapidly after 2006. It is very likely, that it was the result of intensive introductions made by hunters and not an effect of the development of previously established populations (Fig. $4 b$ ).

As a consequence of introductions, the area of forests inhabited by mouflons outside mountains has extended. In 1986, mouflons inhabited a single Olsztynek F.D., occupying the area of 1,400 ha. Almost 30 years later the relevant forest area amounted 
to more than 70 thousand hectares. It was, nevertheless, still smaller than the area occupied in 2010 , i.e. in the period of the most intensive introduction activities, which amounted to ca. 100 thousand hectares. During the period of the fastest increase in the numbers of mouflons the area occupied by them increased by nearly $50 \%$ (Fig. 4c).

The history of the local populations that emerged in that time was very diverse. Taking into account the dynamics of releases, populations with history not exceeding three years dominated there. There were 21 of them, accounting for $43 \%$, of all populations which emerged after 1981. Populations that have lasted increasingly longer have become gradually less numerous. Only a few populations survived longer than 13 years. These were represented by mouflons in the following forest districts: Lubin and Dretyń (13-15 years), Wałcz, Olsztynek, Szubin and Lubin - for more than 16 years (7\% of all populations) (Fig. 4d).

Collected material shows that out of 49 introductions, more than a half (28) ended in failure. The time survived by released groups of mouflons was diverse but the largest group (18 introductions, 64\%) comprised animals which did not survive more than three years. About $20 \%$ of introductions failed when the animals were still recorded four to six years after introduction. In cases where the animals were still observed after seven to nine years, the percentage of failure was only ca. 10\%. Only in one case - in Niedźwiady F.D. (northern Poland) - the local population ceased to exist after 11 years.

Quite the opposite age structure pattern was found in the populations which still exist. The least numerous (15\%) are the populations which were set up in 2009-2010, whereas the most numerous were those which have been around for more than 12 years. No failures were registered among introductions in which animals survived for more than 12 years (Fig. 5).

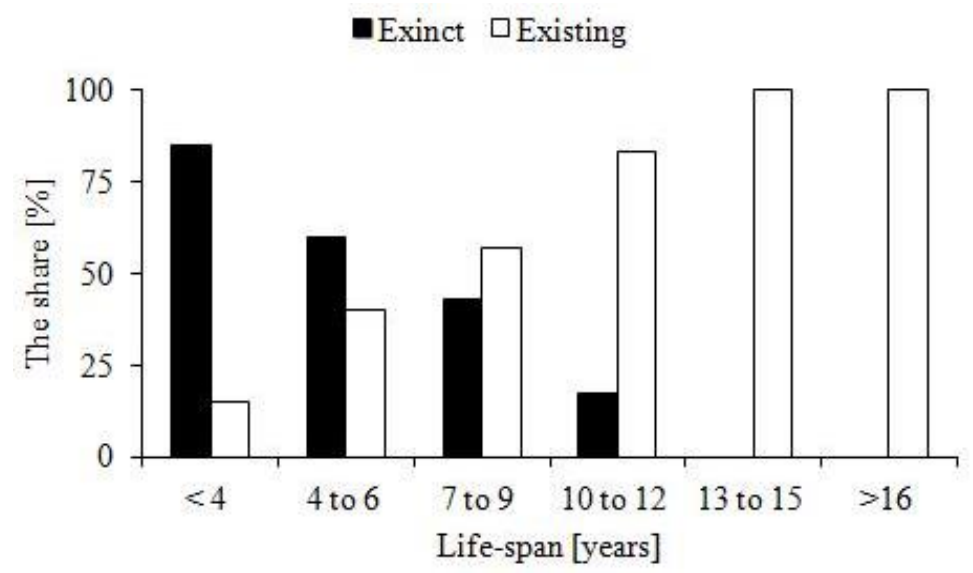

Figure 5. Proportions of populations introduced after 1982 and extinct before 2014 and population which exist till 2014 in different classes of life-spans

It seems that the period of 7 to 9 years from the establishment of a population is the threshold value, because at this point similar number of introductions ended in success as in failure. If the mouflons survived this period, the chance for forming a permanent population was, and still is, very high (Fig. 5).

For 23 populations of mouflons currently inhabiting lowland Poland it means that a mere ten of them (five which, so far, survived 10 to 12 years, two surviving 13 to 15 years, and three that have lived more than 16 years) stand a major chance of 
continued survival. The duration of populations which were set up after 2007 (i.e. three populations which, so far, have survived 1-3 years, four surviving 4-6 years, and four surviving 7-9 years) does not yet guarantee that stable populations will emerge in these places.

No less dynamic changes occurred in mountain populations, i.e. those in the Polish part of the Sudeten. During the years 1982-2014 there were two evident increases in the numbers of mouflons, separated by periods of stabilization. Between 1982 and 1989 there was the first period of stabilization during which the population of mouflons fluctuated around ca. 500 individuals. Only three years later, the number of mouflons doubled, probably due to the migration of animals from the Czech Republic. This situation lasted, with minor fluctuations (between 1,200 and 1,600 individuals) for nearly 19 years, until 2008. Since 2009 the number of mouflons again grew at a more rapid rate reaching its peak value of 2274 individuals in 2013; so far, this is the greatest value ever recorded in the post-war history of mouflons in Poland (Fig. 6).

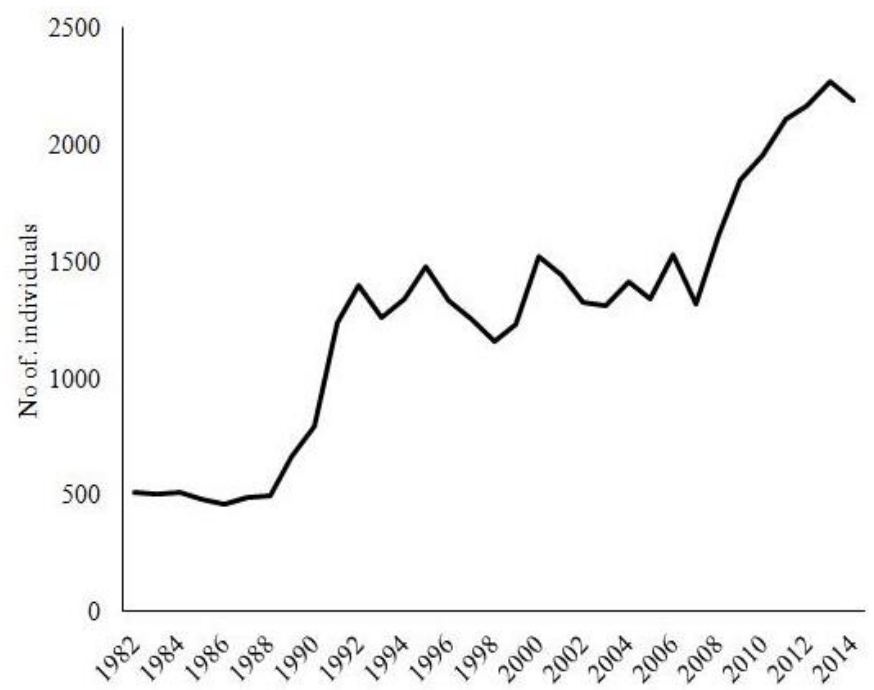

Figure 6. Changes in the number of mouflons in Polish part of the Sudeten Mt. in the period 1982-2014

The changes of the numbers of mouflon populations in mountains, were not similar in various ranges within the Sudeten. In some of the ranges, the local populations grew steadily whereas in the others declines were noted. Systematic growth was registered in the Sowie and Bardzkie mountain where the most numerous populations of the Sudeten mouflons lived (ca. 48\%). Since 1982, the population there has increased almost fourfold, from ca. 250 to 1,000 animals. A similar phenomenon was observed in the Śnieżnik massif, where only a small fraction $(5 \%)$ of the whole Sudeten population lives. Also there, over three decades, the number of mouflons tripled, from ca. 30 individuals in 1982 to more than 100 in 2014.

Undoubtedly the highest dynamics characterized the populations from the Wałbrzyskie and Kamienne mountain ranges. Mouflons inhabiting those areas, whose number in 1982 was estimated at ca. 20 individuals, now represent the second largest population in Poland amounting to more than 500 animals.

During the same time, population declines were noted in two ranges of the Sudeten mountains. It was most evident in the Karkonosze inhabited by a small 
group of mouflons (ca. 2.5\%). While in 1982 ca. 140 mouflons lived in that area, 32 years later, i.e. in 2014 - only 54 individuals were still present. Thus, there was an almost threefold drop, although it is important to take into account that this location is near the Polish-Czech border so the animals at large are likely to move freely across this border. Therefore, the numbers estimated on only one side of the frontier can be misleading and certainly cannot represent accurately the dynamics of the population.

This situation is similar to that of mouflons living in the Stołowe mountains. These mouflons came as migrants from the Czech Republic and they are probably a fraction of much more numerous population inhabiting the Stołowe mountains on the Czech side. Nevertheless, an almost tenfold increase in their numbers was noted in the 19982014 period. Since 1998, when the first 7 individuals were observed, the population has risen to ca. 70 animals and now constitutes ca. $3.2 \%$ of all mouflons in the Sudeten mountains according to the 2014 inventory.

The most dynamic changes were recorded in the Kaczawskie mountains. Mouflon population increased there between 1982 and 1994 and then regressed until 2008. This stage was followed, again, by a period of gradual growth which continues until the present day. The amplitude of changes which occurred over the last 30 years in the Kaczawskie mountains shows that this fairly numerous population $(16.5 \%)$ is still unstable and reacts quickly both to factors limiting its number and to the releases which were carried out in this place in order to improve the quality of individuals (Fig. 7).

\section{Constraints and reasons of failures}

Even though the intensity of introductions of mouflons in Poland was different in various time intervals within the 1902-2014 period, some of the introductions turned out to be a success whereas others were failed. The failure rate in introductions of mouflons reaches nearly $50 \%$ and is yet another feature which distinguishes this species from other wild ungulates in Poland. Not all of the introductions were properly documented, nor their history described in scientific journals or those popularising the knowledge of game management or nature protection. Nevertheless, the available references permit determination of the chief causes of failed introductions or major declines in their numbers (Table 1).

Poaching and predation by stray dogs was the most often cited cause of failed mouflon introductions until the 1960s. According to the available information, there was no place in Poland where introduced mouflons would not fall victim to poachers or stray dogs. In some cases, they brought about the disappearance of the whole local populations, e.g. in the Sieraków, Wronki and Ciechanów F.D. (Krysztofik, 1962; Nowak, 1968; Solarz, 2011), or adversely affected the population dynamics, as was the case of some mountainous populations (Nowak, 1968; Łabęcki, 2008). In the post-war period, two or more adverse phenomena frequently overlapped with one another. For example, in the Sudeten, mouflon migrations between Poland and Czech Republic occurred in parallel with poaching and stray dogs, leading to a considerable drop in the number of mouflons in the area of the mountains belonging to Poland. But a reverse phenomenon i.e. rapid increase in "Polish" mouflon populations in the Sudeten area was also observed (Eabęcki, 2008). It is probably due to the proximity of much larger mouflon population at the Czech side of the mountains which has prevented the animals inhabiting the Polish side of the Sudeten mountains from disappearing. 


$$
-1006-
$$

Table 1. Known reasons of decline or collapse of local populations of mouflons in Poland since 1902

\begin{tabular}{|c|c|c|c|c|c|}
\hline Location & $\begin{array}{c}\text { Population set } \\
\text { up } \\
\text { [year] }\end{array}$ & $\begin{array}{c}\text { Decline or } \\
\text { extinction } \\
\text { [year/s] }\end{array}$ & $\begin{array}{l}\text { Reason of decline or } \\
\text { extinction }\end{array}$ & $\begin{array}{c}\text { Does } \\
\text { population } \\
\text { exist? }\end{array}$ & Source \\
\hline Bardzkie Mt.* & 1902 & $\begin{array}{c}1948,1952 \\
1987\end{array}$ & $\begin{array}{l}\text { Poaching and stray dogs, } \\
\text { parasitic diseases, inbred }\end{array}$ & Yes & $\begin{array}{l}\text { Łabęcki, } 2008 \\
\text { Solarz, } 2011\end{array}$ \\
\hline Sowie Mt.* & 1902 & 1952,1987 & $\begin{array}{l}\text { Poaching and stray dogs, } \\
\text { severe winters, lack of } \\
\text { protection and supplemental } \\
\text { feeding, migration to C.R., } \\
\text { parasitic diseases, inbred }\end{array}$ & Yes & $\begin{array}{c}\text { Nowak, } 1968 \\
\text { Nowakowski et al., 2009; } \\
\text { Olech and Fruba, } 2009\end{array}$ \\
\hline Karkonosze * & 1912 & 1952 & $\begin{array}{l}\text { Poaching and stray dogs, } \\
\text { severe winters, lack of } \\
\text { protection and supplemental } \\
\text { feeding, migration to C.R. }\end{array}$ & Yes & $\begin{array}{c}\text { Solarz, } 2011 \\
\text { Nowakowski et al., } 2009\end{array}$ \\
\hline Wałbrzyskie Mt.* & 1914 & 1952,1958 & $\begin{array}{c}\text { Severe winters, lack of } \\
\text { protection and supplemental } \\
\text { feeding, poaching }\end{array}$ & Yes & $\begin{array}{l}\text { Nowak, } 1968 \\
\text { Labęcki, } 2008\end{array}$ \\
\hline M. Śnieżnik * & 1928 & 1952 & $\begin{array}{l}\text { Poaching and stray dogs, } \\
\text { severe winters, lack of } \\
\text { protection and supplemental } \\
\text { feeding, migration to C.R. }\end{array}$ & Yes & $\begin{array}{c}\text { Nowak, } 1968 \\
\text { Łabęcki, } 2008 \\
\text { Nowakowski et al., } 2009\end{array}$ \\
\hline Starzawa & 1934 & 1944 & $\begin{array}{c}\text { Consequences of World } \\
\text { War II }\end{array}$ & No & Szczepkowski, 1951 \\
\hline Spała & 1937 & 1939 & $\begin{array}{c}\text { Consequences of World } \\
\text { War II }\end{array}$ & No & Szczepkowski, 1951 \\
\hline Kartuzy & 1939 & 1946 & World War II, post war time & No & Szol and Olej, 1946 \\
\hline Sieraków & 1942 & 1950 & $\begin{array}{l}\text { Poaching, predation of } \\
\text { wolfs }\end{array}$ & No & $\begin{array}{l}\text { Nowak, } 1968 \\
\text { Solarz, } 2011\end{array}$ \\
\hline Wronki & 1942 & 1950 & $\begin{array}{l}\text { Poaching, predation of } \\
\text { wolfs }\end{array}$ & No & $\begin{array}{l}\text { Nowak, } 1968 \\
\text { Solarz, } 2011\end{array}$ \\
\hline Bytom & 1947 & 1947 & $\begin{array}{l}\text { Single observation of 9-10 } \\
\text { mouflons and unknown } \\
\text { reason of disappearance }\end{array}$ & No & Ostrowski, 1949 \\
\hline Kamienne Mt. * & 1948 & 1952,1958 & $\begin{array}{c}\text { Severe winters, lack of } \\
\text { protection and supplemental } \\
\text { feeding, poaching, } \\
\text { migration to C.R. }\end{array}$ & Yes & $\begin{array}{l}\text { Łabęcki, } 2008 \\
\text { Nowak, } 1968\end{array}$ \\
\hline Stołowe Mt. * & 1948 & 1957 & $\begin{array}{c}\text { Poaching and stray dogs, } \\
\text { lack of supplemental } \\
\text { feeding }\end{array}$ & Yes & $\begin{array}{c}\text { Łabęcki, } 2008 \\
\text { Nowakowski et al., } 2009\end{array}$ \\
\hline Toruń & 1949 & 1949 & $\begin{array}{c}\text { Single observation of } 2 \\
\text { mouflons of unknown origin } \\
\text { and unknown reason of } \\
\text { disappearance }\end{array}$ & No & Nowak, 1968 \\
\hline Ciechanów & 1950 & 1950 & $\begin{array}{l}\text { Poaching, translocation of } \\
\text { animals to unknown place }\end{array}$ & No & Nowak, 1968 \\
\hline Świętokrzyskie Mt. & 1951 & 1960,1973 & $\begin{array}{c}\text { Stray dog, poaching, } \\
\text { migration to Świętokrzyski } \\
\text { National Park }\end{array}$ & No & $\begin{array}{l}\text { Krysztofik, } 1962 \\
\text { Solarz, } 2011\end{array}$ \\
\hline Kaczawskie Mt.* & 1967 & 1981 & $\begin{array}{l}\text { Migration to adjacent } \\
\text { hunting grounds }\end{array}$ & Yes & Łabęcki, 2008 \\
\hline Jedwabno & 1981 & 1982 & $\begin{array}{l}\text { Migrations, predation of } \\
\text { stray dogs }\end{array}$ & No & Jakubowski and Zalewski, 2000 \\
\hline Stare Jabłonki & 1987 & 1988 & Migrations & No & Jakubowski and Zalewski, 2000 \\
\hline Nowe Ramuki & 1988 & 1990 & Predation of stray dogs & No & Jakubowski and Zalewski, 2000 \\
\hline
\end{tabular}

*Parts of Sudeten Mt. 


$$
-1007 \text { - }
$$
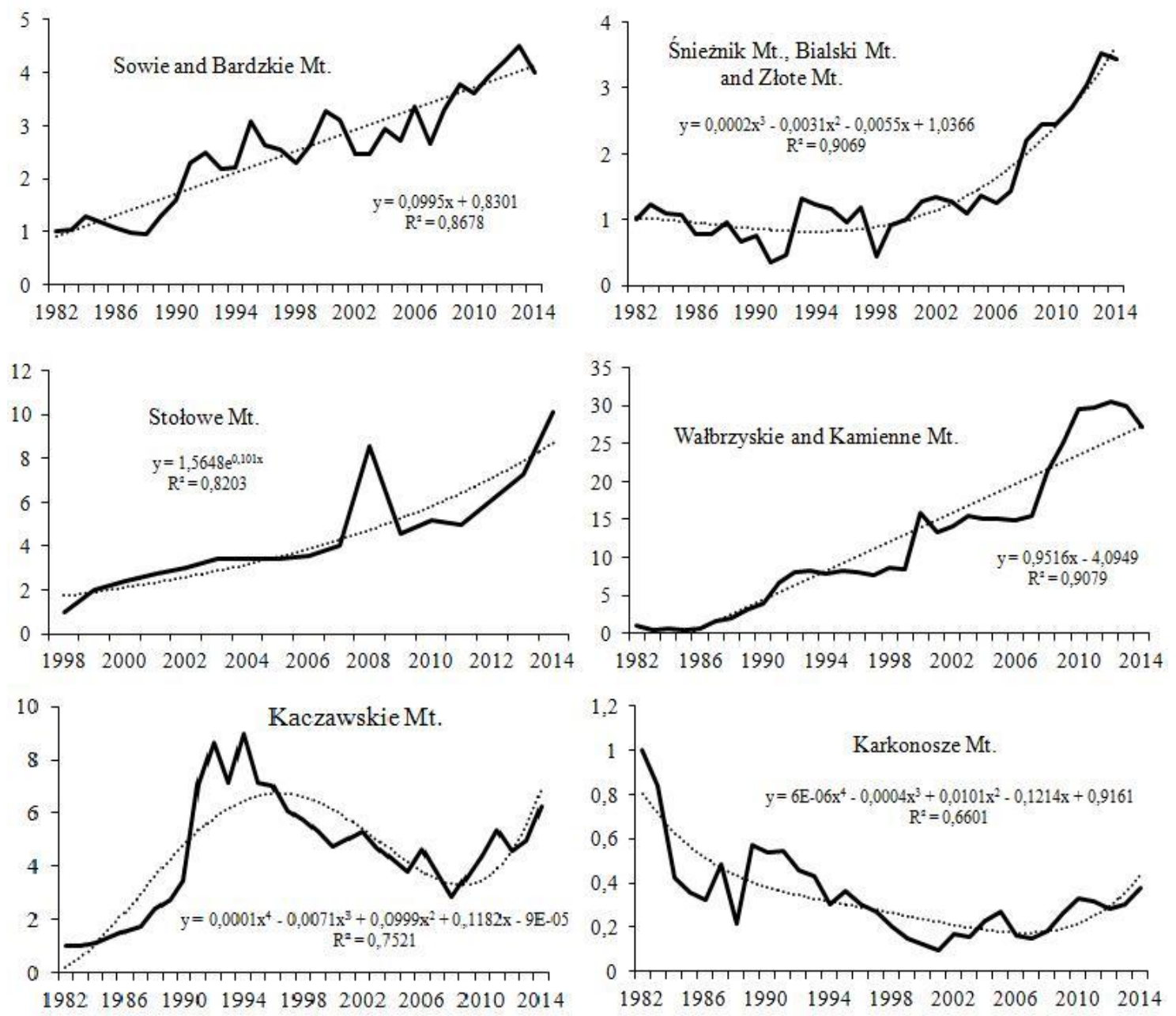

Figure 7. Trends and relative changes in the number of mouflons in different parts of Sudeten Mt. in the period 1982-2014 (The number of mouflons in 1982, and 1998 for Stolowe Mt. was taken as 1)

In the case of Świętokrzyskie mountains, the only mountains apart from the Sudeten, disturbances caused by poaching and predation by stray dogs have resulted in the migration of mouflons from the sites of release to the nearby National Park where, deprived of additional feeding during severe winters, their population vanished in early 1970s (Krysztofik, 1962; Solarz, 2011).

Severe winters in Poland and the lack of winter extra feeding, particularly at times of thick snow cover, was the third most often cited reason for the disappearance of mouflon populations. Moreover, it was true not only for the area of mountain ranges but for lowlands as well (Table 1).

Poland's climate may also be disadvantageous to mouflons because both its high humidity (good for survival of parasites) and severe winters (debilitating the animals) favour parasitic diseases. Negative effects of both factors on mouflons were reported e.g. by Skálova et al. (2007), and Krozova et al. (2008) from Czech Republic as well as by Meana et al. (1996). As a rule, parasitic infection does not have a lethal effect on the host. However, under unfavourable conditions, parasitic invasions can significantly affect the health and survival rate of the animals. In Poland, according to Kozakiewicz 
and Maszewska (1984), Sołtysiak and Bartczak (1991) and Pacoń (1994) pulmonary and gastrointestinal parasitosis are most frequent and the most harmful.

More or less spontaneous migrations of mouflons also accounted for their failed introductions. A detailed analysis of this phenomenon was presented by Jakubowski and Zalewski (2000) on the basis of unsuccessful introductions in northeastern Poland in the Masuria region in three forest districts: Jedwabno, Stare Jabłonki, and Nowe Ramuki. After their introductions, the animals remained only a short time near the place of their release, and afterwards migrated, for unknown reasons, from a dozen to several dozens of kilometres. They vanished there only one or two years later.

Towards the end of the 1990s, another factor began to negatively affect local populations. It was the inbreeding among animals closely related genetically as they lived in small populations composed of initially small numbers of individuals. Initially the inbreeding was expressed as the deformation of male mouflon horns and mostly concerned isolated populations in the Sudeten mountains (Nowakowski et al., 2009; Olech and Fruba, 2009).

For the time being, the most serious effect of the deformation was the lowering of the value of the horns as hunting trophies, however the problem seems to be serious enough to prompt some forest districts (e.g. Jawor, Bardo Śląskie, Jugów, and Świdnica) to begin, on a major scale, to release mouflons from other localities in order to increase the genetic diversity of the populations living locally (Łabęcki, 2008; Olech and Fruba, 2009).

\section{Current number and distribution}

According to data collected for this study, in spring 2014 Polish mouflon population totalled an estimated 2,901 mouflons. This data differs by 57 animals from the official statistics amounting to 2,958 mouflons (GUS Forestry, 2014). This difference probably results from the different status of mouflons kept in enclosures. According to Polish Hunting Law only mouflons living at large in hunting areas should be considered as hunted animals and only these animals are counted in spring and recorded in hunting statistics. Unfortunately, after purchasing mouflons hunters usually keep them in enclosures for a few years and for e.g bookkeeping reasons, they take them into account in hunting statistics.

In Poland, mouflons currently inhabit 24 locations in two types of landscape: mountains (the Sudeten mountains) and lowlands (predominantly in western Poland) (Fig. 8). Their population numbers are very diverse, both between the mountainous areas and lowlands, as well as within the Sudeten mountains themselves. Some $75 \%$ of the whole Polish population of mouflons live in mountains. The most numerous populations occur in the Sowie and Bardzkie ranges, within the eastern Sudeten mountains. Their total numbers are estimated at ca. 1,000 individuals which corresponds to ca $50 \%$ of all mountain mouflons. The next sizeable populations are those of the Wałbrzyskie and Kamienne ranges where inventories show ca. 500 animals $(25 \%)$, followed by the population in the Kaczawskie range - ca. 350 individuals $(16 \%)$. The least numerous populations of mouflons live in the Karkonosze and Stołowe mountains where 50 and 70 mouflons were recorded, respectively, in the spring of 2014 (Fig. 8). It must be nevertheless underlined that, because of the transboundary nature of the Karkonosze and Stołowe mountains, these mouflons are certainly parts of more numerous Czech populations living on the southern slopes of the Sudeten mountains. 


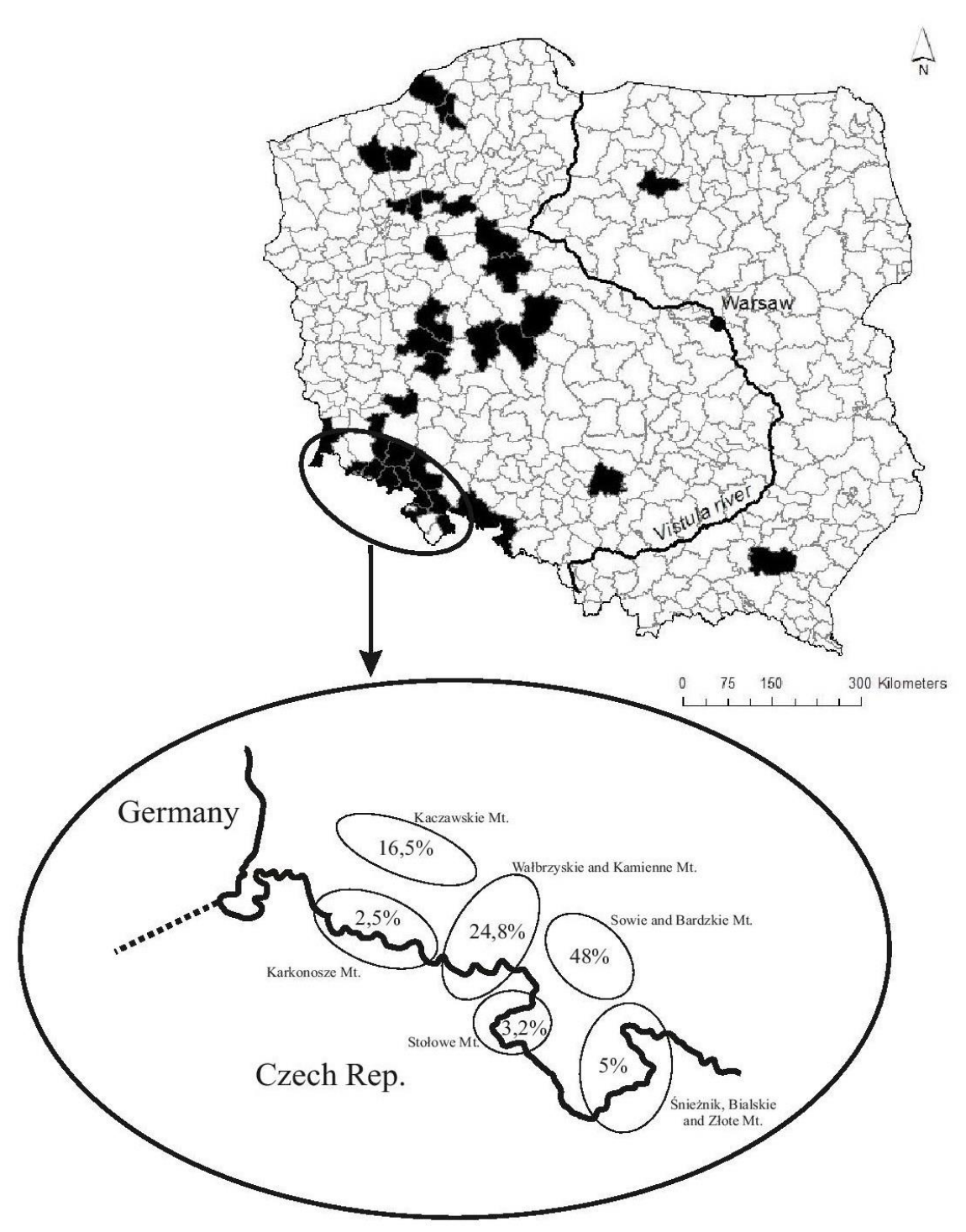

Figure 8. Location of isolated populations of mouflons in forest districts in lowland Poland and distribution of mouflons in different ranges of Sudeten Mt. in 2014

The remaining purposeful introductions or migrations of mouflons resulted in the emergence and continued existence of local populations in 23 sites, situated mainly in the lowland forests of western Poland. The only exception is Prudnik F.D. on the eastern border of the Sudeten mountains. Because of the close vicinity of mouflons living in the Sowie mountains, this population, which emerged in 2003, could be considered as mouflons of the Sudeten mountains.

Another exceptional local population includes mouflons living in southeastern Poland, in Strzyżów F.D. This population came to exist in 2005 as an initiative of local hunters (Kiebała, 2013). Despite unfavourable climate in the Carpathian region, the mouflons multiplied from ca. 20 individuals in 2005 to more than 40 individuals in 2014. Today, they represent the southeastern most population of mouflons in Poland.

Similar situation prevails in northeastern Poland, in Olsztynek F.D. The local mouflons living in the area and inhabiting the forests of the Dynowskie foothills, were 
introduced by local hunters 18 years ago and it was the sole successful introduction among several attempts made in the Mazuria region. According to hunting statistics, there were ca. 60 mouflons in the Olsztynek F.D. in the spring of 2014. This population size was reached from the initial herd of some 6-8 animals brought there in 1986. They all have survived, as well as those in Strzyżów, only because they were protected by the hunters.

All the remaining lowland populations of mouflons in Poland occur in the western part of the country, predominantly in the Wielkopolska region, and in the central part of Pomerania. This land is notable for its greater woodiness and it is generally less populated compared with central or southern parts of the country. Moreover, the western part of Poland, which features the Atlantic climate, is warmer, has more precipitation and less severe winters than central and eastern Poland which have a severe continental climate (hot and dry summers, freezing winters).

In Poland, (except for two National Parks in the Stołowe and Karkonosze mountains) mouflons inhabit managed forests typical of local soil and climatic conditions. As a rule, these are forests transformed by humans in previous centuries, and are presently predominated by economically important tree species. In the lowlands, mouflons were released into potentially fertile habitats typical of mixed forests and mixed coniferous forests, such as Galio-silatici - Carpinetum, Pino - Quercetum, Leycobrio - Pinetum, and Fago - Carpinetum. Unfortunately, due to human activities these forests only partly retained their natural floristic composition. By the time mouflons were introduced, these were Scots pine (Pinus sylvestris)-dominated forests whereas such species typical of these habitats as oaks (Quercus sp.), birches (Betula sp.), lime trees (Tilia sp.) and hornbeams (Carpinus betulus) constituted (and they still constitute today) only small proportions of the tree stands.

Forest districts of Grodziec, Sarbia, and Jastrów represent mouflon breedings in typical commercial pine forests where the proportion of Scots pine exceeds $90 \%$ (Table 2).

In the Sudeten mountains the situation is very much alike. Taking into account soil and climatic conditions, these mountains should be characterized by strongly diversified plant species - both in the ground cover and in the tree stands. Unfortunately, most forests of the region are dominated by single-species spruce (Picea abies) forests set up for the needs of industry in the XIX and XX centuries (Zoll, 1963; Trampler et al., 1990).

Table 2. Locations and environmental characteristics of forests occupied by local populations of mouflons in Poland in 2014

\begin{tabular}{|c|c|c|c|c|c|}
\hline $\begin{array}{c}\text { F.D. location } \\
\text { (expect Sudeten } \\
\text { Mt.) }\end{array}$ & $\begin{array}{c}\text { Year of } \\
\text { introduction }\end{array}$ & GPS & $\begin{array}{c}\text { Forest area* } \\
\text { [ha] }\end{array}$ & Landscape & $\begin{array}{c}\text { Dominant type of vegetation } \\
\text { T: Canopy trees }(\%) \\
\text { P: Potential plant communities }\end{array}$ \\
\hline Sudeten Mt. & 1902 & $\begin{array}{l}50.478 \mathrm{~N} \\
16.461 \mathrm{E}\end{array}$ & Ca. 350000 & $\begin{array}{c}\text { Lowland (300-500 m a.s.1.) } \\
\text { and medium (500-1500 m } \\
\text { a.s.1.) mountains } \\
\text { (1602 m a.s.1. - highest } \\
\text { point) }\end{array}$ & $\begin{array}{c}\text { T: Picea abies (70\%) } \\
\text { P: Dentario enneaphyllidis }- \text { Fagetum, } \\
\text { Luzulo nemorosae - Fagetum, Abieti - } \\
\text { Picetum (montanum) }\end{array}$ \\
\hline Jawor & 1969 & $\begin{array}{l}50.512 \mathrm{~N} \\
15.543 \mathrm{E}\end{array}$ & 15060 & $\begin{array}{c}\text { Low and medium hills } \\
\text { (690 m a.s.1. - highest } \\
\text { point) }\end{array}$ & $\begin{array}{c}\text { T: Quercus sp. (45\%), Picea abies (32\%) } \\
\text { P: Galiosilatici-Carpinetum, Dentario } \\
\text { enneaphylli-Fagetum }\end{array}$ \\
\hline Sławno & 1973 & $\begin{array}{l}54.409 \mathrm{~N} \\
16.626 \mathrm{E}\end{array}$ & 24210 & Lowland & $\begin{array}{c}\text { T: Pinus sylvestris }(51 \%) \text {, Fagus silvatica } \\
(15 \%) \\
\text { P: Stellario-Carpinetum typicum, Melico- } \\
\text { Fagetum }\end{array}$ \\
\hline
\end{tabular}


Nasiadka et al.: A comprehensive over 100 years history of mouflon (Ovis musimon) in Poland: from the promising beginning in 1902 to questionable future in 2014 - a case study of wildlife management history $-1011-$

\begin{tabular}{|c|c|c|c|c|c|}
\hline Olsztynek & 1986 & $\begin{array}{l}53.579 \mathrm{~N} \\
20.206 \mathrm{E}\end{array}$ & 18230 & $\begin{array}{l}\text { Lowland/hills } \\
\text { (312 } \mathrm{m} \text { a.s.1. }- \text { highest } \\
\text { point) }\end{array}$ & $\begin{array}{c}\text { T: Pinus sylvestris (52\%), Betula sp. } \\
(14 \%) \\
\text { P: Stellario-Carpinetum typicum, }\end{array}$ \\
\hline Wałcz & 1986 & $\begin{array}{l}53.371 \mathrm{~N} \\
16.470 \mathrm{E}\end{array}$ & 16090 & Lowland & $\begin{array}{c}\mathrm{T}: \text { Pinus sylvestris }(85 \%) \\
\text { P: Leucobryo-Pinetum, Fago-Quercetum } \\
\text { petraeae, Pino-Quercetum }\end{array}$ \\
\hline Lubin & 1991 & $\begin{array}{l}51.486 \mathrm{~N} \\
16.135 \mathrm{E}\end{array}$ & 21320 & Lowland & $\begin{array}{c}\text { T: Pinus sylvestris (76\%) } \\
\text { P: Galiosilvatici-Carpinetum, } \\
\text { Calamagrostio-Quercetum petraeae }\end{array}$ \\
\hline Szubin & 1999 & $\begin{array}{l}53.065 \mathrm{~N} \\
17.666 \mathrm{E}\end{array}$ & 26730 & Lowland & $\begin{array}{c}\text { T: Pinus sylvestris }(82 \%) \\
\text { P: Leucobryo-Pinetum, Pino-Quercetum, } \\
\text { Ficario-Ulmetum chrysosplenietosum }\end{array}$ \\
\hline Dretyń & 2000 & $\begin{array}{l}54.092 \mathrm{~N} \\
17.010 \mathrm{E}\end{array}$ & 14300 & Lowland & $\begin{array}{c}\text { T: Pinus sylvestris }(82 \%) \\
\text { P: Melico-Fagetum, Pino-Quercetum, } \\
\text { Fago-Quercetum petraeae }\end{array}$ \\
\hline Prudnik & 2003 & $\begin{array}{l}50.393 \mathrm{~N} \\
17.461 \mathrm{E}\end{array}$ & 16770 & $\begin{array}{l}\text { Low and medium hills } \\
\text { (785 } \mathrm{m} \text { a.s.1. }- \text { highest } \\
\text { point) }\end{array}$ & $\begin{array}{c}\text { T: Quercus sp. }(42 \%) \text {, Pinus sylvestris } \\
(21 \%) \\
\text { P: Galiosilvatici-Carpinetum }\end{array}$ \\
\hline Kościan & 2003 & $\begin{array}{l}51.995 \mathrm{~N} \\
16.727 \mathrm{E}\end{array}$ & 17920 & Lowland & $\begin{array}{c}\text { T: Pinus sylvestris (70\%) } \\
\text { P: Galiosilvatici-Carpinetum, Ficario- } \\
\text { Ulmetum chrysosplenietosum }\end{array}$ \\
\hline Gołąbki & 2004 & $\begin{array}{l}52.774 \mathrm{~N} \\
17.841 \mathrm{E}\end{array}$ & 15710 & Lowland & $\begin{array}{c}\text { T: Pinus sylvestris }(75 \%) \\
\text { P: Galio silvatici-Carpinetum }\end{array}$ \\
\hline Grodziec & 2004 & $\begin{array}{l}51.991 \mathrm{~N} \\
17.980 \mathrm{E}\end{array}$ & 31700 & Lowland & $\begin{array}{c}\text { T: Pinus sylvestris }(93 \%) \\
\text { P: Galio silvatici-Carpinetum, Pino- } \\
\text { Quercetum }\end{array}$ \\
\hline Strzyżów & 2005 & $\begin{array}{l}49.880 \mathrm{~N} \\
21.883 \mathrm{E}\end{array}$ & 29020 & $\begin{array}{c}\text { Low and medium hills } \\
(534 \mathrm{~m} \text { a.s.l. - } \text { highest point })\end{array}$ & $\begin{array}{c}\text { T: Abies alba }(32 \%), \text { Fagus silvatica } \\
(32 \%) \\
\text { P: Tilio-Carpinetum typicum, Deutario } \\
\text { glaudulosae-Fagetum }\end{array}$ \\
\hline Karczma Borowa & 2006 & $\begin{array}{l}51.854 \mathrm{~N} \\
16.631 \mathrm{E}\end{array}$ & 13110 & Lowland & $\begin{array}{c}\text { T: Pinus sylvestris }(70 \%) \\
\text { P: Galio silvatici-Carpinetum, Ficario- } \\
\text { Ulmetum chrysosplenietosum }\end{array}$ \\
\hline Konin & 2007 & $\begin{array}{l}52.357 \mathrm{~N} \\
18.385 \mathrm{E}\end{array}$ & 17990 & Lowland & $\begin{array}{c}\text { T: Pinus sylvestris }(78 \%) \\
\text { P: Pino-Quercetum, Galio silvatici- } \\
\text { Carpinetum, Potentillo albae-Quercetum } \\
\text { typicum }\end{array}$ \\
\hline Sarbia & 2007 & $\begin{array}{l}52.997 \mathrm{~N} \\
16.798 \mathrm{E}\end{array}$ & 19920 & Lowland & $\begin{array}{c}\text { T: Pinus sylvestris }(93 \%) \\
\text { P: Galio silvatici-Carpinetum, Leucobryo- } \\
\text { Pinetum }\end{array}$ \\
\hline Mirosławiec & 2008 & $\begin{array}{l}53.330 \mathrm{~N} \\
16.180 \mathrm{E} \\
\end{array}$ & 14500 & Lowland & $\begin{array}{c}\text { T: Pinus sylvestris (85\%) } \\
\text { P: Fago-Quercetumpetraeae }\end{array}$ \\
\hline Jastrowie & 2009 & $\begin{array}{l}53.401 \mathrm{~N} \\
16.660 \mathrm{E}\end{array}$ & 17540 & Lowland & $\begin{array}{c}\text { T: Pinus sylvestris (91\%) } \\
\text { P: Galio silvatici-Carpinetum, Fago- } \\
\text { Quercetum petraeae, Leucobryo-Pinetum }\end{array}$ \\
\hline Warcino & 2009 & $\begin{array}{l}54.228 \mathrm{~N} \\
16.934 \mathrm{E}\end{array}$ & 19320 & Lowland & $\begin{array}{c}\text { T: Pinus sylvestris }(73 \%) \\
\text { P: Melico-Fagetum, Luzulopilosae- } \\
\text { Fagetum }\end{array}$ \\
\hline Złoty Potok & 2010 & $\begin{array}{l}50.747 \mathrm{~N} \\
19.252 \mathrm{E}\end{array}$ & 27280 & Lowland & $\begin{array}{c}\text { T: Pinus sylvestris }(78 \%) \\
\text { P: Pino-Quercetum, Tilio-Carpinetum, } \\
\text { Leucobryo-Pinetum }\end{array}$ \\
\hline Konstantynowo & 2010 & $\begin{array}{l}52.283 \mathrm{~N} \\
16.822 \mathrm{E}\end{array}$ & 18410 & Lowland & $\begin{array}{c}\text { T: Pinus sylvestri (68\%), Quercus sp. } \\
18 \%) \\
\text { P: Galiosilvatici-Carpinetum }\end{array}$ \\
\hline Świdwin & 2012 & $\begin{array}{l}53.856 \mathrm{~N} \\
15.783 \mathrm{E}\end{array}$ & 23850 & Lowland & $\begin{array}{c}\text { T: Pinus sylvestris (55\%), Fagus silvatica } \\
(12.8 \%) \\
\text { P: Fago-Quercetum petraeae }\end{array}$ \\
\hline Jarocin & 2012 & $\begin{array}{l}51.974 \mathrm{~N} \\
17.467 \mathrm{E}\end{array}$ & 24230 & Lowland & $\begin{array}{l}\text { T: Pinus sylvestris (68\%), Quercus sp. } \\
\text { (20\%) } \\
\text { P: Galio silvatici-Carpinetum, Ficario- } \\
\text { Ulmetum chrysosplenietosum }\end{array}$ \\
\hline Połczyn & 2014 & $\begin{array}{l}53.740 \mathrm{~N} \\
16.219 \mathrm{E}\end{array}$ & 24400 & Lowland & $\begin{array}{c}\text { T: Pinus sylvestris (58\%), Fagus silvatica } \\
\text { (14\%) } \\
\text { P: Melico-Fagetum, Pino-Quercetum }\end{array}$ \\
\hline
\end{tabular}

*Total forested area of F.D. 
As regards potential plant communities, the forests of the Sudeten mountains can provide ample fodder and shelter to mouflons, particularly in the lower parts of the mountains. The vegetation of Dentario enneaphzllidis - Fagetum, Luzulo nemorosae Fagetum, and Abietiti - Picetum montanum communities, which occupy ca. $70 \%$ of the mountain area at an altitude between $500 \mathrm{~m}$ a.s.l. and $1000 \mathrm{~m}$ a.s.l. (Gorzelak, 1995), can constitute a sufficient fodder base both in summer time (grasses, herbs) and in winter (shrubs) (Table 2).

To sum up, in present-day Poland, mouflons live in small, isolated groups inhabiting managed mountain and lowland forests with impoverished natural potential diversity.

\section{Discussion}

The history of the mouflon in Poland closely matches the experience obtained in many other efforts to introduce animals for hunting purposes or for their protection (Griffith et al., 1989; Kleiman, 1989; Wolf et al. 1996). This species came into existence, both in Poland and other countries of continental Europe, following some trends reigning in game management at the turn of the XIX and XX centuries. In line with these, the owners of great estates, depending on their tastes and financial resources imported various animal species for hunting. These animals, usually after short time spent in quarantine enclosures, were released into the environment and there often bred under the care of the owners and then hunted down (Long, 2003). In Poland, the principles for importing mouflons have not changed significantly with time. Changes consisted in the replacement of landowners by hunting clubs and the estates - by hunting grounds. The basic mechanism of keeping mouflons in the wild has remained unchanged. Namely, it involves the permanent and far-reaching protection of the species in its natural environment which - as it turns out - is the key factor for the survival of local populations.

Compared with other introductions, the fortunes of mouflons in Poland have demonstrated relatively high effectiveness of their introductions (ca. 50\%). Fischer and Lindenmayer (2000) in their analysis of more than 180 cases of reintroductions, supplementations, and translocations made over 20 years, showed that, depending on the criteria they applied, the success rate of introductions only rarely exceeded $30 \%$, irrespective of the animal species involved. Obviously, there is a separate question of the satisfaction felt by the hunting community who would definitely welcome an even higher percentage of successful introductions (Fischer and Lindenmayer, 2000).

The reasons for failed introductions of mouflons in Poland have turned out to be partly convergent with results obtained by other authors. Wolf et al. (1996), in their reanalysis of 421 cases of reintroductions described by Griffith et al. (1989), compiled the ranking of 19 factors with either positive or negative impact on the success of the actions undertaken. Among other factors they included: the quality of the environment, the number of animals introduced, the improvement of living conditions of animals, predation, hunting, competition etc.

The reasons for the disappearance of ca. 50\% of local populations of mouflons in Poland, and what is more, soon after their formation, fit at least three factors which are also stressed by Wolf et al. (1996) as being important. These are: poaching - which prevailed particularly in the post-war period, predation by stray dogs, and to a lesser extent by wolves, and finally, severe environmental conditions in winter. The latter factor is compatible with habitat improvement, and primarily with supplemental feeding 
in winter. The number of introduced mouflons and the frequency of introductions are also important. These are also compatible in the case of the species under consideration. For example, in the Sudeten mountains, the introduction of a small number of animals resulted in inbreeding. As a consequence, additional introductions had to be carried out. In this case, the survival of the population would be rather unrealistic in the long run, and human intervention (subsequent introductions) would be necessary.

As opposed to the ranking given by Wolf et al. (1996), the success of the introduction of mouflons in Poland only slightly depended on the quality of the environment. All Polish introductions were performed in forests whose stand compositions were mostly distorted. Moreover, their plant communities were typical of other localities. In lowland Poland, the only exception could be that of the Olsztynek F.D. where there are some kind of hills. A thesis can thus be put forward that it was not so much the quality of habitat but rather the protection and supplemental feeding which had and still has an effect on the survival of mouflons in Poland. However, this aspect has to do with economic burden which is another important factor responsible for the success or failure of reintroduction. This problem was mentioned e.g. by Lindburg (1992), and - with respect to reintroduction projects of other species - also by Kleiman et al. (1991), Bennet (1992), as well as Bangs and Fritts (1996).

Another, separate issue, undoubtedly pertaining not only to the presence of mouflon in Poland and its future, is the necessity to undertake studies that meet the needs of society and decision-makers in order to define the relationship between the objectives of present game management stemming e.g. from the Convention on the Conservation of European Wildlife and Natural Habitats (and the European Charter on Hunting and Biodiversity), and the remnants of old fashions and habits involving alien game animals, disregarding their traditional, economic or recreational importance. What strategy should be adopted for alien species that are already permanently associated with the places of their introduction, are socially accepted, and over time have become not only a hunting attraction?

In the case of the Polish mouflon, the wolf population that has been growing for last decades (Chapron et al., 2014) probably can significantly reduce the number or even eliminate the mouflon from currently inhabited places. However, natural mechanisms will not always „eliminate” questions about other, often numerous alien species. According to official data, there may be more than 300 alien animal species in Poland (Głowaciński et al., 2012). There are also species clearly associated with the history of hunting, such as: fallow deer (Dama dama), sika deer (Cervus nippon), American mink (Mustela vison), raccoon dog (Nyctereutes procyonoides), raccoon (Procyon lotor), muskrat (Ondatra zibethicus) or even a pheasant (Phasianus colchicus), which has been a permanent element of the Polish agricultural landscape for centuries.

The change in the approach to wildlife management, which results from the state of knowledge, understanding of natural processes and social expectations, still leaves open questions as to the future of alien species.

\section{Conclusions}

Studies on the history and current distribution of mouflons in Poland lead to several detailed conclusions:

1. In Poland, mouflons inhabit two types of environment, the highlands in the Sudeten mountains, and lowlands - mainly in the western, warmer part of the country. 
2. Local lowland populations are small isolated groups of animals living in the commercial forests typical of the respective regions. Mountain populations in the nearborder zone probably remain in contact with mouflons in the Czech Republic. In the other ranges of the Sudeten mountains they also form isolated populations.

3. The main factors affecting the dynamics of mouflon populations in Poland include: severe winters, lack of supplemental feeding, predation by stray dogs, and the consequences of inbreeding. Another significant factor affecting the future of mouflons may also be the development of the wolf population in Poland.

A separate issue, which should certainly be of interest to scientists (not only ecologists, but also sociologists, historians, etc.) is the question of redefining the term "alien species". Over 100 years ago, the introduction of animals beyond their natural range was not questioned. This was often done for hunting purposes. With time, it turned out that some of these introductions were ineffective (e.g. 50\% of mouflon introduction in Poland). The consequences of some have a practically small or ambivalent impact on the surrounding environment (pheasant, muskrat), and some have an unfavorable impact (sika deer, American mink, Canadian beaver). However, all of them pose an ethical problem in their further treatment - to accept, maintain or eliminate populations. For example, in modern societies, would there be consent to the elimination of a pheasant that is common in the environment and well known in society? Or, is it only historically justified to maintain a niche mouflon which, though small in number but still locally plays an important historical and social role?

Acknowledgements. The authors would like to thank Lucjan Łabęcki from the Regional Directorate of State Forests in Wrocław for their help in collecting historical data on mouflons in the Sudeten Mountains. We also thank the Research Station of the Polish Hunting Association in Czempin for providing source data about mouflons in hunting clubs in Poland.

\section{REFERENCES}

[1] Bangs, E. E., Fritts, S. H. (1996): Reintroducing the gray wolf to central Idaho and Yellowstone National Park. - Wildlife Society Bulletin 24: 402-413.

[2] Barker, G. (2006): The Agricultural Revolution in Prehistory. Why Did Foragers Become Farmers? - Oxford University Press. London.

[3] Bennet, J. (1992): A glut of gibbons in Sarawak - is rehabilitation the answer? - Oryx 26: 157-164.

[4] Bobek, B., Frąckowiak, W., Furtek, J., Merta, D. (2014): Integration of introduced mouflons with the local population in the Sudeten Mountains. - Balkan Journal of Wildlife Research 1(1): 82-86.

[5] Bobrinskij, J. N., Kuznecow, B. A., Kuzjakin, A. P. (1944): Identifier of Mammals. CCCP, Moscow (in Russian).

[6] Brachmański, A. (2011): We will not exterminate the mouflon. Interview with Andrzej Tetke, district hunter from Wałbrzych. - Łowiec Polski 2: 16-18 (in Polish).

[7] Cerkal, R., Muska, F. (2010): Damage caused by wild game animals to field crops in the Czech Republic - a historical summary from 1786 to the year 2005. - Journal für Kulturplanzen 62(2): 35-41.

[8] Chapron, G., Kaczensky, P., Linnell, J. D. C., von Arx, M., Huber, D., Andrén, H., López-Bao, J. V., Adamec, M., Álvares, F., Anders, O., Balčiauskas, L., Balys, V., Bedő, P., Bego, F., Blanco, J. C., Breitenmoser, Urs., Brøseth, H., Bufka, L., Bunikyte, R., Ciucci, P., Dutsov, A., Engleder, T., Fuxjäger, Ch., Groff, C., Holmala, K., Hoxha, B., 
Iliopoulos, Y., Ionescu, O., Jeremić, J., Jerina, K., Kluth, G., Knauer, F., Kojola, I., Kos, I., Krofel, M., Kubala, J., Kunovac, S., Kusak, J., Kutal, M., Liberg, O., Majić, A., Männil, P., Manz, R., Marboutin, E., Marucco, F., Melovski, D., Mersini, K., Mertzanis, Y., Mysłajek, R. W., Nowak, S., Odden, J., Ozolins, J., Palomero, G., Paunović, M., Persson, J., Potočnik, H., Quenette, P. Y., Rauer, G., Reinhardt, I., Rigg, R., Ryser, A., Salvatori, V., Skrbinšek, T., Stojanov, A., Swenson, J. E., Szemethy, L., Trajçe, A., Tsingarska-Sedefcheva, E., Váňa, M., Veeroja, R., Wabakken, P., Wölfl, M., Wölfl, S., Zimmermann, F., Zlatanova, D., Boitani, L. (2014): Recovery of large carnivores in Europe's modern human-dominated landscapes. - Science 346(6216): 1517-19.

[9] Chessa, B., Pereira, F., Arnaud, F., Amorim, A., Goyache, F., Mainland, I., Kao, R. R., Pemberton, J. M., Beraldi, D., Stear, M. J., Alberti, A., Pittau, M., Iannuzzi, L., Banabazi, M. H., Kazwala, R. R., Zhang, Y. P., Arranz, J. J., Ali, B. A., Wang, Z., Uzun, M., Dione, M. M., Olsaker, I., Holm, L. E., Saarma, U., Ahmad, S., Marzanov, N., Eythorsdottir, E., Holland, M. J., Ajmone-Marsan, P., Bruford, M. W., Kantanen, J., Spencer, T. E., Palmarini, M. (2009): Revealing the history of sheep domestication using retrovirus integrations. - Science 324: 532-536.

[10] Dębiec, T. (2014): Difficult decision. - Głos Lasu 4: 20-22 (in Polish).

[11] Fischer, J., Lindenmayer, D. B. (2000): An assessment of the published results of animal relocations. - Biological Conservation 96: 1-11.

[12] Geist, V. (1991): On the taxonomy of giant sheep (Ovis ammon Linnaeus, 1766). Canadian Journal of Zoology 69(3): 706-723.

[13] Głowaciński, Z., Okarma, H., Pawłowski, J., Solarz, W. (eds.). (2012): Alien Species in the Fauna of Poland. - Institute of Nature Protection Polish Academy of Science i Cracow, Cracow.

[14] Gorzelak, A. (1995): Forests and forest management in the Sudeten Mountains. - Prace IBL (B) 25: 7-35 (in Polish).

[15] Griffith, B., Scott, J. M., Carpenter, J. W., Reed, C. (1989): Translocation as a species conservation tool: status and strategy. - Science 245: 477-480.

[16] GUS - Forestry 2014 (2014): Statistical Information and Elaborations. - Central Statistical Office, Warsaw.

[17] Heindleder, S., Kaupe, B., Wassmuth, R., Janke, A. (2002): Molecular analysis of wild and domestic sheep questions current nomenclature and provides evidence for domestication from two different subspecies. - Proceedings of the Royal Society, London (B) 269: 893-904.

[18] Jakubowski, M., Zalewski, K. (2000): Muffelwild in Masuren - Erfolge und Misserfolge bei der Einbürgerung. - Zeitschrift für Jagdwissenschaft 46: 45-50.

[19] Jezierski, W. (1955): Mouflon (monographic sketch). - Pomorsko-poznański Biuletyn Łowiecki 9(32): 20-31 (in Polish).

[20] Kiebała, M. (2013): Introduction and management of the mouflon population (Ovis aries musimon, Linnaeus, 1758) in the Strzyżów Forest District. - Dissertation. Postgraduate studies. Wszechnica Polska University, Warsaw (in Polish).

[21] Kleiman, D. G. (1989): Reintroduction of captive mammals for conservation. BioScience 39: 152-161.

[22] Kleiman, D. G., Beck, B. B., Dietz, J. M., Dietz, L. A. (1991): Costs of a re-introduction and criteria for success: accounting and accountability in Golden Lion Tamarin Conservation Program. - Symposia of the Zoological Society London 62: 125-142.

[23] Kozakiewicz, B., Maszewska, I. (1984): Occurrence and treatment of mouflon parasitosis (Ovis musimon L.) in breeding conditions at a hunting center in the Wielkopolska Region. - Medycyna Weterynaryjna 9: 536-538 (in Polish).

[24] Krozova, V., Lamka, J., Szotáková, B., Vokral, I., Srpová, V., Urbánková, M., Kubícek, V., Nobilis, M., Skálová, L. (2008): Dicrocoeliosis of Old Mouflon Ewes - Effect on Biotransformation Enzymes and Metabolism of Anthelmintics In Vitro. - The Open Veterinary Science Journal 2(1): 23-32. 
[25] Krysztofik, E. (1962): Mouflons in the Świętokrzyski National Park. - Łowiec Polski 23/24: 11 (in Polish).

[26] Łabęcki, L. (2008): Mouflon (Ovis musimon) in Lower Silesia, Poland. - Dissertation. Postgraduate Studies. Agricultural University in Cracow, Cracow (in Polish).

[27] Lindburg, D. G. (1992): Are wildlife reintroductions worth the cost? - Zoo Biology 11: $1-2$.

[28] Long, J. L. (2003): Introduced Mammals of the World: Their History, Distribution and Influence. - CSIRO Publishers, Collingwood.

[29] Lydekker, R. (1913): Catalogue of the Ungulate Mammals in the British Museum (National History). Vol. 1. Artiodactyla. - British Museum, London.

[30] Meana, A., Luzón-Peña, M., Santoago-Moreno, J., DeBulnes, A., Gómez-Bautista, M. (1996): Natural infection by gastrointestinal and bronchopulmonary nematodes in mouflons (Ovis musimon) ant their response to netobimin treatment. - Journal of Wildlife Disease 32(1): 39-43.

[31] Nadler, C. F., Lay, D. M., Hassinger, J. D. (1971): Cytogenetic analyses of wild sheep populations in northern Iran. - Cytogenetics 10: 137-152.

[32] Nadler, C. F., Korobitsina, K. V., Hoffmann, R. S., Vorontsov, N. N. (1973): Cytogenetic differentiation, geographic distribution and domestication of palearctic sheep (Ovis). Zeitschrift für Säugetierkunde 38: 109-125.

[33] Nasiadka, P., Wajdzik, M., Skubis, J. (2015): Current state of research on mouflon (Ovis musimon) as a basis for management, protection or elimination of this species from Poland. - Sylwan 159(5): 381-391 (in Polish).

[34] Nasonov, N. (1923): Distribution geographique des mouton sauvages du monde ancient. - Akademija Nauk SSSR, St. Petersburg (in Russian).

[35] Nowak, E. (1968): Mouflon in Poland. - Łowiec Polski 11: 4-5 (in Polish).

[36] Nowakowski, P., Chudoba, K., Piasecki, M. (2009): European muflon (Ovis orientalis musimon Schreber, 1782) in the ecosystem of Lower Silesia. - Annales Universitatis Mariae Curie-Skłodowska Lublin - Polonia, Sectio EE XXVII(4): 7-13.

[37] Olech, W., Fruba, A. (2009): Attempt to Link Genetic Profile to Occurrence Horn Deformation in the Polish Population of the Mouflon (Ovis Musimon). - Final Report on the Expertise for the Directorate General of State Forests Carried Out at the Department of Genetics and General Animal Breeding, Faculty of Animal Sciences, Warsaw University of Life Sciences, Warsaw (in Polish).

[38] Ostrowski, J. (1949): Mouflons. - Łowiec Polski 1/2: 10-12 (in Polish).

[39] Pacoń, J. (1994): Mouflon, deer and roe deer parasites from Lower Silesia. - Wiadomości Parazytologiczne 40(3): 279-292 (in Polish).

[40] Payne, S. (1968): The origin of domestic sheep and goats: a reconsideration in the light of the fossil evidence. - Proceedings of the Prehistoric Society 34: 368-384.

[41] Piegert, H., Uloth, W. (2000): Das Europäische Mufflon. - DSV-Verlag GmbH, Edition Naturlife, Hamburg.

[42] Riley, S. J., Decker, D. J., Carpenter, L. H., Organ, J. F., Siemer, W. F., Mattfeld, G. F., Parsons, G. (2002): The Essence of Wildlife Management. - Wildlife Society Bulletin 30(2): 585-593.

[43] Simmons, A. H. (2007): The Neolithic Revolution in the Near East; Transforming Human Landscape. - The University of Arizona Press, Tucson.

[44] Skálová, L., Kríová, V., Cvilink, V., Szostakova, B., Storkánova, L., Velik, J. (2007): Mouflon (Ovis musimon) dicrocoeliosis: effect of parasitosis on the activities of biotransformation enzymes and albendazole metabolism in liver. - Veterinary Parasitology 146(3-4): 254-262.

[45] Solarz, W. (2011): Muflon Ovis Ammon Linnaeus, 1758. - In: Głowaciński, Z.; Okarma, H.; Pawłowski, J.; Solarz, W. (eds.) Alien Species in the Fauna of Poland. Institute of Nature Protection Polish Academy of Science in Cracow, Cracow. 
[46] Soltysiak, Z., Bartczak, R. (1991): Invasion of pulmonary nematodes from the Protostrongylidae family in the mouflons living in the Sowie Mountains. - Medycyna Weterynaryjna 47(4): 160-161 (in Polish).

[47] Szczepkowski, J. (1951): Muflon. - PWRiL, Warszawa (in Polish).

[48] Szczęśniak, E. (2011): The presence of mouflons (Ovis aries musimon) in Poland - is it really necessary? - Chrońmy Przyrodę Ojczystą 2: 99 (in Polish).

[49] Szol, J. T., Olej, N. (1968): Mouflons in Poland. - Łowiec Polski 3(48): 119 (in Polish).

[50] Tomiczek, H., Türcke, F. (2003): Das Muffelwild. - Franck-Kosmos Verlag GmBH \& Co KG, Stuttgart.

[51] Trampler, T., Kliczkowska, A., Dmyterko, E., Sierpińska, A. (1990): Forest and Nature Regionalization on Ecological and Physiographic Basis. - PWRiL, Warszawa (in Polish).

[52] Tsalkin, V. I. (1951): Mountain sheep of Europe and Asia: materials on the fauna and flora of the USSR. - Moscow Society of Naturalists, New Series, Zoology Department 27: 255-265 (in Russian).

[53] Valdes, R., Nadler, C. F., Bunch, T. D. (1978): Evolution of wild sheep in Iran. Evolution 32: 56-72.

[54] Wajdzik, M., Witek, K., Nasiadka, P., Skubis, J. (2014): Trophy quality of mouflons in the Bardzkie Mountains. - Sylwan 158(12): 911-919 (in Polish).

[55] Wilson, D., Reeder, D. M. (eds.) (2005): Mammal Species of the World. A Taxonomic and Geographic Reference. - Johns Hopkins University Press, Baltimore.

[56] Wolf, C. M., Griffith, B., Reed, C., Temple, S. A. (1996): Avian and mammalian translocations: update and reanalysis of 1987 survey data. - Conservation Biology 10: 1142-1154.

[57] Zoll, T. (1963): Analysis of the condition of forests in the Sudeten Mountains. - Zeszyty Problemowe Podstaw Nauk Rolniczych 37: 123-144 (in Polish). 